\title{
Seismo-electromagnetic phenomena in the western part of the Eurasia-Nubia plate boundary
}

\author{
H. G. Silva ${ }^{1}$, M. Bezzeghoud ${ }^{1}$, J. P. Rocha ${ }^{1}$, P. F. Biagi ${ }^{2}$, M. Tlemçani ${ }^{1}$, R. N. Rosa ${ }^{1}$, M. A. Salgueiro da Silva ${ }^{3}$, \\ J. F. Borges ${ }^{1}$, B. Caldeira ${ }^{1}$, A. H. Reis ${ }^{1}$, and M. Manso ${ }^{4}$ \\ ${ }^{1}$ Geophysical Centre of Évora and Physics Department, ECT, University of Évora, Portugal \\ ${ }^{2}$ University of Bari and Inter-Department Centre for the Evaluation and Mitigation of the Volcanic and Seismic Risk, Italy \\ ${ }^{3}$ Department of Physics and Astronomy, FCUP, University of Porto, Portugal \\ ${ }^{4}$ EDISOFT, Lazarim, Portugal
}

Received: 10 October 2010 - Accepted: 10 December 2010 - Published: 28 January 2011

\begin{abstract}
This paper presents a work that aims to monitor seismo-electromagnetic phenomena in the Western Part of the Eurasia-Nubia Plate Boundary. This region has a significant tectonic activity combined with relatively low electromagnetic noise levels, rendering high quality seismoelectromagnetic measurements possible. An overview of the seismicity of this region is presented and the research plan is discussed accordingly.
\end{abstract}

\section{Introduction}

It is known that low-frequency (ultra (ULF), very (VLF), and low-frequency (LF)) electromagnetic waves produce more convincing earthquake precursors (compared to higher frequencies) because of less contamination, large skin depth, and low attenuation, Chauhan et al. (2009). Thus, two seismo-electromagnetic phenomena (SEM) will be considered: ULF electromagnetic field emissions, Telesca et al. (2008), and VLF/LF radio broadcastings, Biagi et al. (2009). With respect to the ULF measurements, magnetometers are planned to be installed in the South of Iberian Peninsula supported by the existing networks of seismic research and a portable ULF station is also under consideration. Regarding the VLF/LF radio broadcastings, a receiver is presently under installation at the University of Évora to monitor radio signals from up to $10 \mathrm{VLF} / \mathrm{LF}$ transmitters to study the seismic activity in the Western Part of the EurasiaNubia Plate Boundary (WENP) region. The system inte-

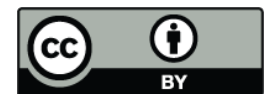

Correspondence to: $\mathrm{H}$. G. Silva (hgsilva@uevora.pt) grates the International Network for Frontier Research on Earthquake Precursors (INFREP). Details about this network are presented in other paper submitted to the same issue, and in this context it will not be restricted to WENP region. Furthermore, these measurements are expected to be complemented with the monitoring of the atmospheric electrical field and the radon levels, since these parameters can provide crucial insights into the physics of SEM phenomenology, Smirnov (2008) and Harrison et al. (2010).

With the development of this research plan it is aimed the collection of novel SEM data emerging from the seismic activity in the WENP region. We expect to address the time variations of the electromagnetic properties of the crust/plate with the strain field, and its relation with composition, temperature and stress fields. Moreover, the interplay between atmospheric (and solar) perturbations with crust perturbations will be monitored, to observe geomagnetic perturbations at different locations.

In this paper, we describe the seismicity of the WENP region, the micro-seismicity of the South of Portugal, and the SEM monitoring future research plan, together with a summary of the expected results.

\section{Seismicity of WENP region}

The western part of the Eurasia-Nubia plate boundary (WENP) starts in the Azores archipelago and goes to the Strait of Gibraltar. This region encloses the transition from an oceanic boundary (between the Azores and the Gorringe Bank), to a continental boundary where Iberia and Africa meet, Grandin et al. (2007a). In the oceanic part, from the Azores archipelago to the Azores-Gibraltar fault

Published by Copernicus Publications on behalf of the European Geosciences Union. 


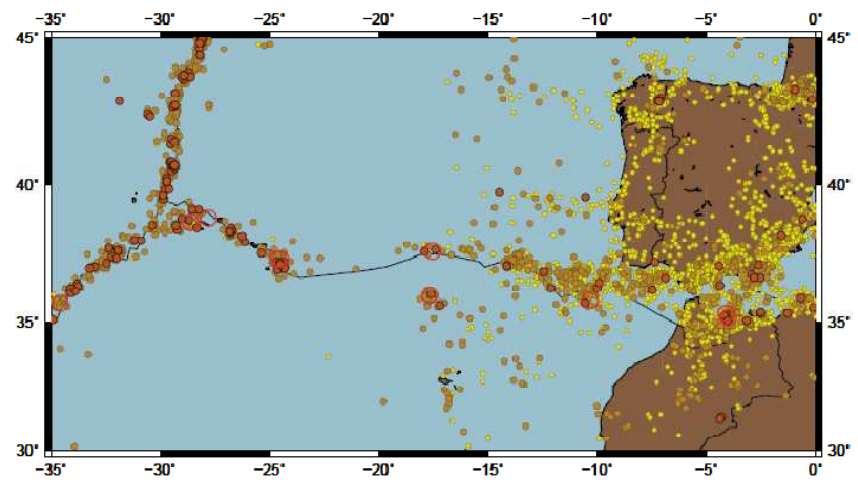

Fig. 1. Seismicity of the western part of the Eurasia-Nubia plate boundary for the period 01/01/1973-17/06/2010 ( $M \geq 3.0$, USGS Data File). Small yellow circles represent seismic events with $3 \leq M<4$, small light brown ones correspond to $4 \leq M<5$, mean orange circles signify $5 \leq M<6$, and big red hollow circles stand for $6 \leq M<9$.

approximately $12^{\circ} \mathrm{W}$, the plate boundary is very well delimited. But, from $12^{\circ} \mathrm{W}$ to $3.5^{\circ} \mathrm{E}$, the boundary is more disperse and embraces a larger area of deformation, this region comprises the Iberia-African area and prolongs to the western part of Algeria, Buforn et al. (2004), Borges et al. (2007, 2008) and Bezzeghoud et al. (2008, 2010). The WENP region can be separated into six fundamental zones (from the Mid-Atlantic Ridge in the west to Algeria in the east) with different seismtectonic behaviors: zone I - The Azores region; zone II - The central region; zone III - The IberoMaghrebian region. In Fig. 1 a picture of this region is presented, Bezzeghoud et al. (2008, 2010).

\subsection{The Azores region}

The seismicity of the Azores is related with the triple point: Eurasian, African and American plate boundaries (Fig. 1). Typically, it presents a complex seismicity composed of moderate magnitudes and shallow depth $(h<40 \mathrm{~km})$ events. In fact, just two earthquakes with $M_{s} \geq 7$ occurred, the first at east of Santa María Island (8 May 1939) and the second between Terceira and Graciosa Islands (1 January 1980). Actually, the major seismic activity is developed on the MidAtlantic Ridge and the North Azores fracture zone, and goes on into the Terceira Ridge. Furthermore, it is known from historical seismicity that large earthquakes occurred in Azores (with maximum modified Mercalli intensities of X), Nunes and Ribeiro (2001).

In short, the seismicity of this region trails much the trend of the islands: roughly ENE from the Mid-Atlantic Ridge to Terceira Island, the 1980 and 1998 earthquakes took place in this zone; and SE from Terceira Island to San Miguel Island, where the 1997 shock appended. Seismic activity then vanishes at $24^{\circ} \mathrm{W}$ where the Terceira Ridge joins with the Gloria fault that is believed to be seismically dormant, as shown in Fig. 1.

\subsection{The central region}

The central region, also represented in Fig. 1, is normally accepted to be an extension of the East Azores Fracture Zone that starts in the Gloria Fault, between the longitudes $23^{\circ} \mathrm{W}$ and $11^{\circ} \mathrm{W}$ and coincides with the previously defined zone III. The East Azores rupture zone, whose direction is around $\mathrm{EW}$, is evidently pertained by the ocean bottom topography, until $18^{\circ} \mathrm{W}$ longitude. From this longitude a complex bathymetry is observed where it is difficult to identify a comprehensible alignment, since it is fulfilled by large submarine mountains and abyssal plains. Along this fracture, various NS similar fractions are recognized with profiles containing significant recent scarps, Searle (1980). Besides, Gloria Fault is a right lateral transform fault, Buforn et al. (1988a) that seems to be presently inactive (Fig. 1). This is probably due to the high return period of earthquakes of high magnitude that can be more than 80 years which is comparable with the existence time of instrumental data from this region, Argus et al. (1989). Moreover, numerous seismic events occurred in the east of the island, Nunes and Ribeiro (2001). As a matter of fact, the occurrence on 25 November 1941, of a $M_{S}=8.4$ earthquake with epicenter placed at the eastern end of the Gloria Fault, claims in support of this interpretation. The strong magnitude event and the associated seismic deformation could be a consequence of the relative and long standing quietness of this fault.

Summing up, the Gloria Fault is characterized by a seismic gap that extends from the $23^{\circ} \mathrm{W}$ to $20^{\circ} \mathrm{W}$. From this longitude to the $11^{\circ} \mathrm{W}$, it presents an EW orientation that engaged different earthquakes, as the strong magnitude events occurred on the 20 May $1931\left(M_{s}=7.1\right), 25$ November 1941 $\left(M_{s}=8.4\right)$ and 25 May $1975\left(M_{s}=7.9\right)$, Bezzeghoud et al. $(2008,2010)$.

\subsection{The Ibero-Maghrebian region}

This part of WENP can be subdivided into three parts: zone A - Gorringe Bank to Cádiz; zone B - enclosing Betic, Rif Cordilleras and Alboran Sea; zone C - northwest Algeria and Tell Mountains. Similar division was made in Buforn et al. (2004), Bezzeghoud et al. (2008, 2010). In effect, intermediate depth activity, $40<h<150 \mathrm{~km}$, is located in regions $\mathrm{A}$ and $\mathrm{B}$ and the deep earthquakes, $h \sim 650 \mathrm{~km}$, are located to the south of Granada, an example of such events is the recent $M_{s}=6.3$ earthquake on 11 May 2010 with $623 \mathrm{~km}$ depth that as a result of being so deep are not of interest for SEM monitoring. The zone intricacy reflects its bathymetry, seismicity, stress regime and tectonics. Indeed, the bathymetry evidences the Gorringe Bank, the Horseshoe Abyssal Plain and the Guadalquivir bank (located west of the Strait of Gibraltar) with a number of seamounts, banks and submarine ridges with important regional crustal thickness variations, Torné et al. (2000), as fundamental aspects. Besides, in land the main geological features are the Betics, the Rif Cordilleras and the Tell Mountains that are a 
consequence of the collision between Eurasia and Africa, and form the Alpine domain. In the Gibraltar western part, from Gulf of Cádiz to Gorringe bank, epicenters are scattered in an EW direction, across about $\sim 100 \mathrm{~km}$ wide, with foci at shallow and intermediate depth. Four significant earthquakes have occurred in this region in the last 50 years: one in the Gulf of Cádiz (15 March 1964; $M_{s}=6.4$ ) and three probably along the Horseshoe fault, at west of the San Vicente Cape (12 December 2009, $M_{w}=5.6 ; 2$ February 2007, $M_{w}=5.9 ; 28$ February $1969, M_{s}=8.0$ ), Udías et al. (1976), Buforn et al. (1988b), Bezzeghoud et al. (2010). Since 2003, an increase in the seismicity of the area enclosing the Gorringe Bank and the Horseshoe Fault (Zone A) has been observed. In particular, the East of $16^{\circ} \mathrm{W}$ region is controlled by a transpressive tectonic regime, with a very low convergence rate of $5.5 \mathrm{~mm} / \mathrm{yr}$ trending NW to NNW, Bezzeghoud et al. (2008, 2010). Such regime conforms the observed maximum horizontal stress direction, Borges et al. (2001) and Bezzeghoud et al. (2008, 2010). Moreover, in this region, the limit between plates occupies a large area with a disseminated deformation that even reaches a NS width of $300 \mathrm{~km}$ close to the Iberia continental margin. Actually the seismicity is spread, even though a vast number of events are concentrated along a $\sim 100 \mathrm{~km}$ extensive band, trending ESEWNW from $16^{\circ} \mathrm{W}$ to $9^{\circ} \mathrm{W}$. In the area, sequences of topographic configurations tending WSW-ENE appear, Borges et al. (2007), Bezzeghoud et al. (2008, 2010). Parallel to the San Vicente canyon, the Horseshoe scarp and the Marquês de Pombal scarp since, at least, the Miocene have undergone deformations. This hypothesis is corroborated by the incidence of oceanic earthquakes with abnormally large magnitude inside the area of dispersed seismic activity alike the 1969 earthquake, with $M_{s}=8.0$, and the historical 1755 Lisbon earthquake, Grandin et al. (2007a, 2007b). On the other hand, historical earthquakes with maximum intensity of IX or X occurred W of San Vicente Cape (Lisbon earthquake in 1755), southern Iberia (1829 and 1884) and in northern Morocco (1909). At least, seismic activity with magnitude range from 3.5 to 5 at intermediate depth $(40<h<150 \mathrm{~km})$ is further present in this region, as extensively described in literature, Munuera (1963), Hatzfeld (1978), Grimison and Cheng (1986), Buforn et al. (1988b, 1991a, 1991b, 1997, 2004), Seber et al. (1996), Serrano et al. (1998), Bezzeghoud et al. $(2008,2010)$. Particularly in the area A, intermediatedepth shocks are diffuse over a $\sim 100 \mathrm{~km}$ broad belt (between $36^{\circ} \mathrm{N}$ and $37^{\circ} \mathrm{N}$ ) that goes EW from $8^{\circ} \mathrm{W}$ to $11^{\circ} \mathrm{W}$. Nevertheless, a large amount of foci (the majority, in fact) at intermediate depth is found in area B, at the eastern side of the Strait of Gibraltar in a thin NS trending band less than $50 \mathrm{~km}$ wide concentrated at $4.5^{\circ} \mathrm{W}$ and expanding from $35^{\circ} \mathrm{N}$ to $37^{\circ} \mathrm{N}$. Therefore, the distribution of intermediatedepth earthquakes is different in area A (EW propensity) from that of area B (NS trend). No intermediate depth seismicity is observed east of $3^{\circ} \mathrm{W}$ in Spain, Morocco or Algeria.

Summarizing, the seismic activity of the Iberia-African re-

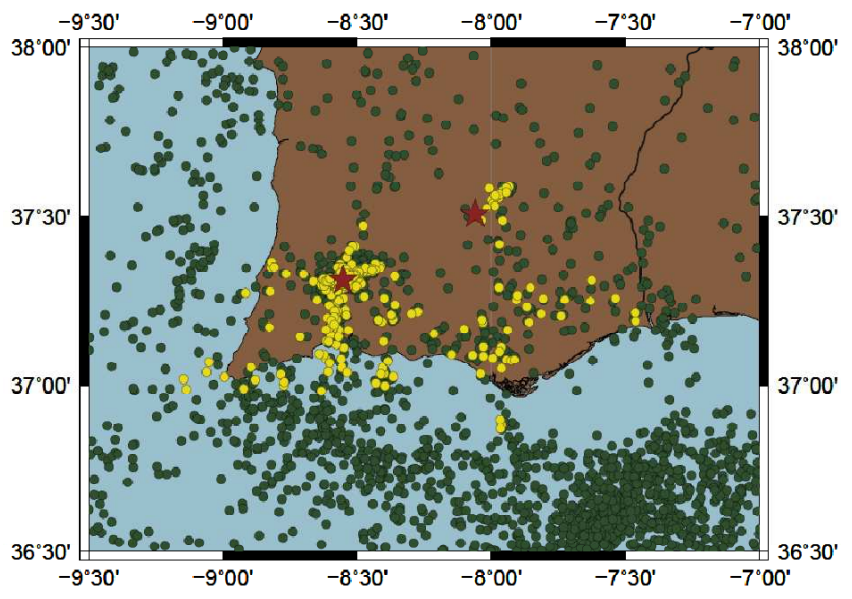

Fig. 2. Yellow circles represent the micro-seismicity $(1<M<3)$ of the South of Portugal acquired with the network described in Rocha et al. (2008), for nearly 4 years of observation. Green circles stand for the seismic records from IM database from 1961-2009. The red stars show the planned locations to host the ULF three-component magnetometers.

gion is dominated by the incidence of moderate magnitude earthquakes, the majority with shallow depth focus in the range $0<h<40 \mathrm{~km}$. Nevertheless, significant seismicity at intermediate depths, $40<h<150 \mathrm{~km}$, with an EW trend and concentrated in Gulf of Cádiz is also present. Yet, another intermediate depth seismicity spot, between $36^{\circ} \mathrm{N}$ and $37^{\circ} \mathrm{N}$, appears in a $100 \mathrm{~km}$ wide area, and it also generates very deep earthquakes ( $h \sim 650 \mathrm{~km}$ ), Buforn et al. (1991a, 1997).

\section{Micro-seismicity of the south of Portugal}

The study of the micro-seismic activity of the south of Portugal is recent, but is revealing rather interesting results. The data here analysed were acquired using both the Portuguese national network supported by Instituto de Meteorologia, IP Portugal (IM) and a seismic monitoring network installed on purpose to this study in the mentioned region, Rocha et al. (2008). In Fig. 2 the micro-seismicity, $M<3$, of this region is presented. It appears that the seismicity in both regions is characterized by low magnitude events, Bezzeghoud et al. (2008). It is clearly possible to define in the region of Monchique epicenter alignments that suggest a correlation with two possible faults newly discovered in this area, Rocha et al. (2008). In the NW region of Almodôvar, it is possible to define a trend of the distribution of epicenters that may indicate the occurrence of an uncharted fault in this zone.

Interestingly, the field compression is in agreement with the regional stress field expected for this region and the resulting collision between the Eurasian plate and African. 


\subsection{Almodôvar region}

The obtained results show the occurrence of reduced magnitude events. Using the proper programs of localization, Klein (1978), and relocation, Waldhaus (2001), it was possible to define a zone of seismic activity in Almodôvar region (see Fig. 2). The seismicity detected in the region of Almodôvar has a tendency according to NE-SW orientation, which becomes more evident with the epicenter redistribution, obtained after the relocation.

\subsection{Monchique region}

The studies undertaken allowed the identification of a relevant seismic activity, with typical magnitudes $1<M<3$ and constrained between 5 and $15 \mathrm{~km}$ depth, around the Monchique region. The seismicity map obtained after the relocation using the previous programs defines a clear alignment of the seismic epicenters in this region, which can be related with two probable faults recently indentified in this area, Rocha et al. (2008). The faults have ENE-WSW and NNE-SSW directions.

\section{SEM monitoring study}

As already pointed out in the introduction the present study integrates two main types of SEM phenomena, one dedicated to the recognition of ULF electromagnetic fields, and the other to the detection of VLF/LF radio broadcasting anomalies, both related with seismic activities. It has three structural objectives: (1) establish an Iberian monitoring network of seismic related ULF electromagnetic emissions, possibly integrated in the existing seismic networks, Caldeira et al. (2007), and the Western Mediterranean Broad-Band Seismological Network (WMBB), Martin et al. (2007); (2) extend the international INFREP network with a new receiver, whose installation is already in progress, in the University of Évora; (3) contribute to the increase of both seismic related ULF and VLF/LF world database. Moreover, these measurements are expected to be complemented with the monitoring of the atmospheric electrical field and the radon levels, since these parameters can give crucial insights into the physics of SEM phenomenology. In this way, multi-parameter assessment of the preparatory stage of the earthquakes is envisaged.

\subsection{Observation of ULF magnetic field emissions}

The detection of ULF electromagnetic fields aims to equip seismic stations, in the south of Iberian Peninsula with threecomponent ULF magnetometers of type LEMI-30 (produced by the Lviv Centre of Space Research, Ukraine) as commonly used in ULF research, Chauhan et al. (2009). A possible location for the initial two equipments is presented in Fig. 2. According to the micro-seismicity previously presented, the following potential regions have been selected:
(1) offshore zone with intermediate and strong magnitude between Gorringe Bank, the Horseshoe Fault and the Gulf of Cádiz; (2) onshore zone with low magnitude - Algarve and south Alentejo (between Monchique and Almodôvar). An important point is that the sensors are installed in specific sites that exhibit significant seismic activity and, simultaneously, low electromagnetic noise levels. These conditions favour detection of SEM phenomena. Moreover, preference will be given to places that already host seismic stations. A portable three-component ULF magnetometer, most probably the LEMI-18 model, will be used in the search for the proper location, by monitoring the electromagnetic activity of the region of interest. Once a specific site is chosen it will be employed in calibration procedures. Nonetheless, this portable magnetometer could also be used for in-situ aftershock studies, typically $M \sim 3-5$, once the mainshock epicentre has been correctly identified. Special attention will be given to man-made noise sources, such as electricity transmission grids, factories, roads, etc., that must be clearly identified to ensure the reliability of the acquired data, Prattes et al. (2008) and Bleier et al. (2009). Our ULF study will be focused on the analysis of low magnitude earthquakes (LME) with $M \leq 4$. These events are frequent in the South of Portugal, but have been almost completely disregarded in literature, as will be discussed in the next session. Finally, the magnetometers will integrate the South European GeoMagnetic Array (SEGMA) array.

\subsection{Observation of $\mathrm{VLF} / \mathrm{LF}$ radio signals}

The recognition of VLF/LF radio broadcasting anomalies is already being performed through two antennas (one for each band) connected to a receiver built by Elettronika (Italy), which is able to acquire up to 10 signals (distributed in these bands). This equipment is frequently employed in similar experiments, Biagi et al. (2009). In Fig. 3 a photograph of the apparatus installation in the University of Évora $\left(38^{\circ} 34^{\prime} \mathrm{N}, 7^{\circ} 54^{\prime} \mathrm{W}, 300 \mathrm{~m}\right.$ a.m.s.l. $)$ is presented. The system was recently installed in the context of the present project and is in operation since 1 September 2010. The receiver integrates the International Network for Frontier Research on Earthquake Precursors (INFREP), shown in Fig. 4, and is expected to monitor signals emitted from active transmitters to study the seismic activity in the WENP region. In fact, the relevant issue when choosing a transmitter is that the radio path from the transmitter to the receiver crosses the epicentral area, Biagi et al. (2008, 2009), so three transmitters out of the ten being examined (already monitored by other INFREP receivers) are located in: Sicily (Italy), $37^{\circ} 07^{\prime} \mathrm{N} / 1^{\circ} 26^{\prime} \mathrm{E}$; Sardinia (Italy), $40^{\circ} 54^{\prime} \mathrm{N} / 09^{\circ} 42^{\prime} \mathrm{E}$; Monaco (France), $43^{\circ} 47^{\prime} \mathrm{N} / 06^{\circ} 09^{\prime} \mathrm{E}$. Once we assure a proper functioning of the system, three frequencies that are now being monitored will possibly be substituted by three other emitters in the west of the Iberian Peninsula: Ponta Delgada (Azores-Portugal), 


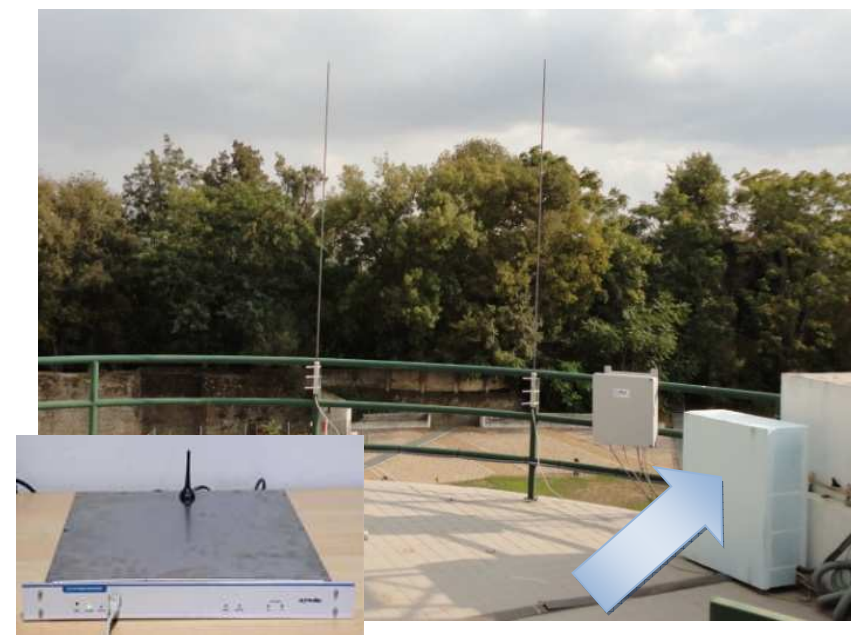

Fig. 3. Photograph of the VLF and LF antennas and the box where receiver is kept (pointed with the blue arrow) at the University of Évora. The inset shows the front panel of the receiver.

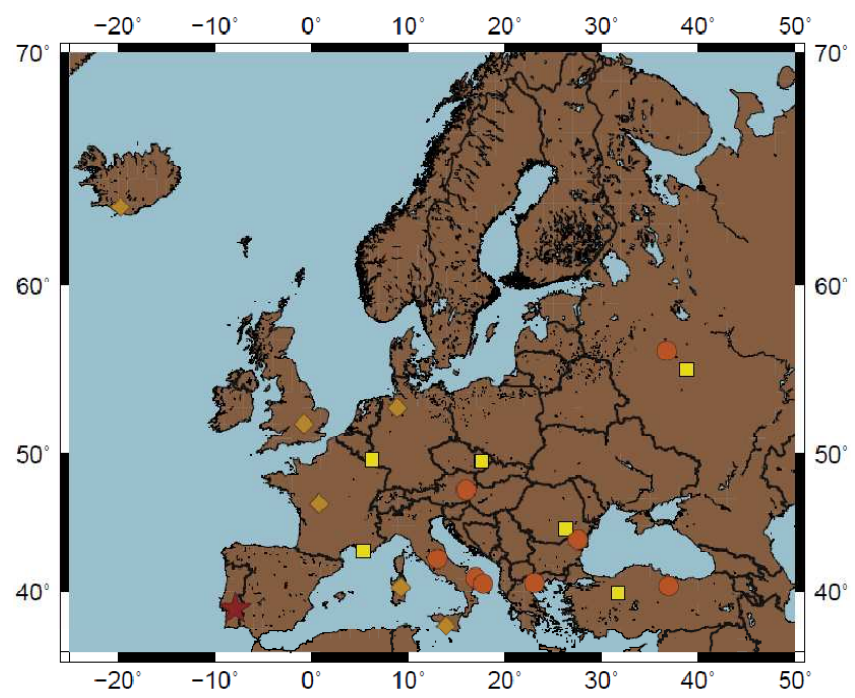

Fig. 4. Representative map of the INFREP showing the location (orange circles) of the five VLF/LF receivers presently in operation. Some transmitters, whose signals are sampled by the different receivers, are also indicated (light brown diamonds represent VLF transmitters and yellow squares LF ones). The new receiver under installation in Mitra (Évora) is pointed with a red star.

Funchal (Madeira-Portugal), Ceuta (Spain). Figure 5 shows the location of the mentioned emitters and the receiver. It is expected that the receiver is able to detect anomalies related with high magnitude earthquakes (HME), $M \geq 5$, in Europe. The data acquired with this equipment will be available to the INFREP community according to the regulation of the network.

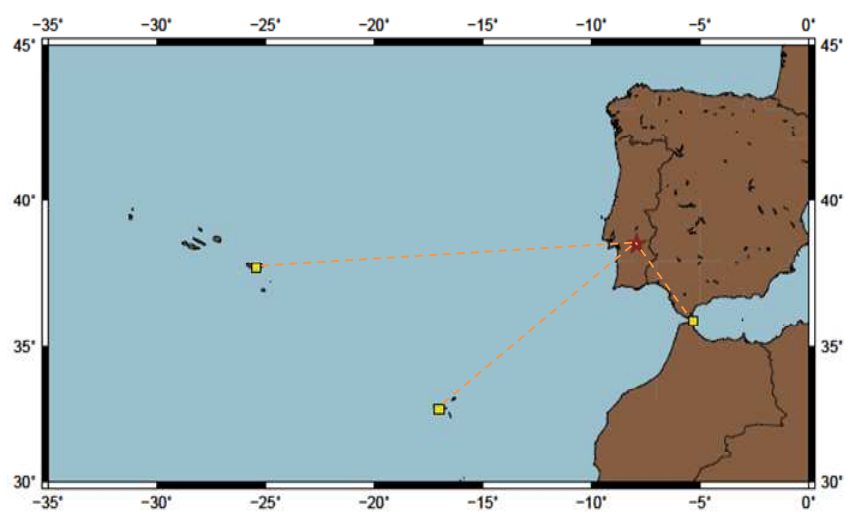

Fig. 5. Map of the planned VLF/LF radio broadcast system: three transmitters (represented by yellow squares) located at Azores (Portugal), Madeira (Portugal) and Ceuta (Spain), and the receiver (shown as a red star) installed at Évora (Portugal).

\subsection{Observation of the Atmospheric Electrical field}

Investigation of $\mathrm{AE}$ anomalies related with seismic activity is by now being preformed through a vertical component of the atmospheric electrical field (VAE) sensor, Keithley Electrometer model JCI 131, installed at the University of Évora (in the same coordinates as the VLF/LF system). This equipment has been in operation during the period of December 2003 to October 2004 and from February 2005 until now. It is prepared for continuous monitoring of the VAE and works in four scales: 2, 20, 200 and $2000 \mathrm{kV} / \mathrm{m}$ with automatic commutations, respectively with the correspondent sensitivity thresholds of $0.1,1,10$ and $100 \mathrm{kV} / \mathrm{m}$. Figure 6 presents a picture of the apparatus. Inspection of the data collected until now is revealing interesting results presented in a paper submitted to this issue, Silva et al. (2010). In the future, it is planned that more VAE sensors could equip the seismic stations that will receive ULF magnetometers, in order to achieve multiple-parameter monitoring.

\subsection{Monitorization of the atmospheric Radon levels}

The Radon levels are monitored using, for the moment (the acquisition of new equipments is being considered), a "Radon Thoron Daughters Meter model $4 \mathrm{~S}$ " built by Silena (a former Italian company) that uses alpha spectrometry and has a sensitivity of $3.7 \mathrm{~Bq} / \mathrm{m}^{3}$ of equilibrium equivalent radon concentration ( $1 \mathrm{mWL})$, and an electronicallyregulated flow-rate of $31 / \mathrm{min}$ with $5 \%$ precision. The apparatus is now under installation at the University of Évora in the same place of the VAE sensor and VLF/LF system to allow multiple parameter assessment of the region. Precursor anomalous Radon levels have been reported for various seismic events, Toutain et al. (1999). Thus monitoring such levels deserves attention by itself. Even so, their direct correlation with SEM could open new insights into the physical 


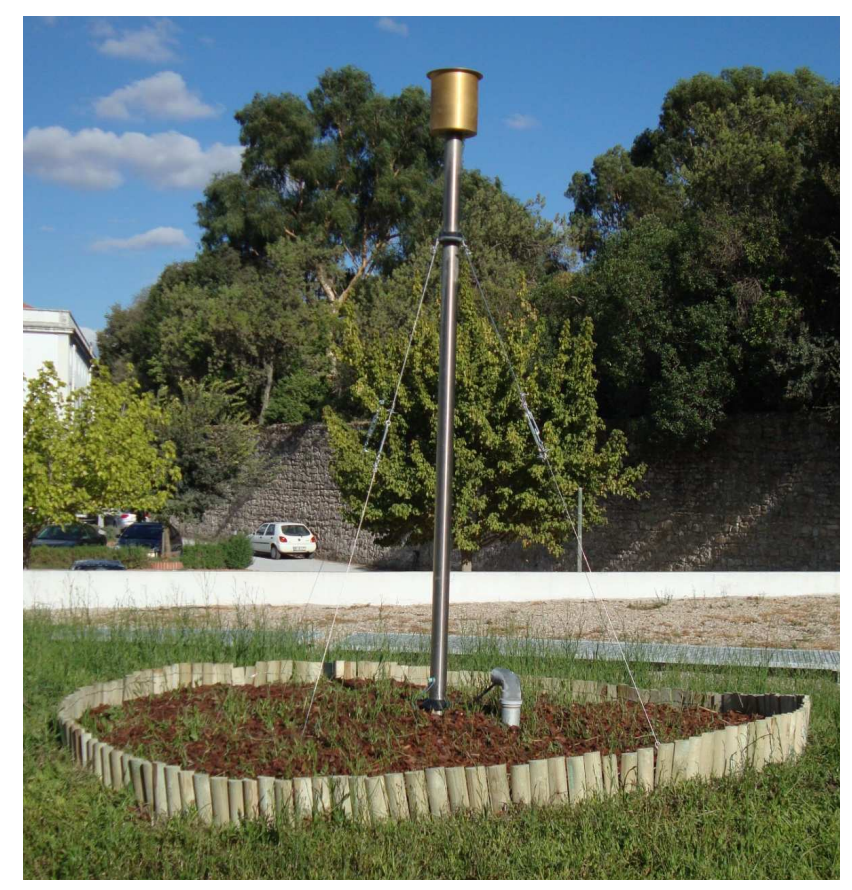

Fig. 6. Photograph of the VAE sensor installed at the University of Évora. The inset is a zoom into the head of the instrument.

mechanisms behind SEM that are the main purpose of this project. Similarly to the VAE sensors, new Radon detectors could, in the future, equip the seismic stations that will host ULF magnetometers.

\section{Discussion}

With this research effort, it is likely that new SEM data linked with seismic activity in the WENP region could emerge and contribute to a better understanding of SEM phenomena. Furthermore, such data could be used in the following objectives: (1) perform the correlation between the ULF and VLF/LF radio signals, for different seismic events, with the atmospheric electrical field and the radon levels; (2) theoretical modelling of the observed phenomena; (3) extend the empirical magnitude versus distance diagram for the detection of abnormal ULF signals preceding HME presented by Hattori et al. (2004) to LME (working below the present detection threshold). In fact, since LME were not considered in the former diagram, the extension of such diagram could provide valuable information about the ULF precursory emissions. Moreover, the study of Gladychev et al. (2010) reveals that observation of LME is feasible if the seismic epicentre is sufficiently close to the ULF station; (4) Explore VLF/LF radio anomalies correlated with HME earthquakes and also LME, already below the empirical threshold for its detection (similar to the ULF case) discussed by Rozhnoi et al. (2004); (5) Search for a relation law between the strength of SEM anomalies and the magnitude and/or local (referred to the place where the sensors will be installed) ground motion of the impending LME. This objective could give an important insight into the driving mechanisms of these phenomena and present a decisive contribution to the development of this field. Obviously, the SEM perturbations caused by LME will be, in principle, very faint and their detection and discrimination from other possible signal sources will represent a real challenge.

As a final remark, it is important to mention that laboratorial experiments concerning the electrical properties of the rocks (for the moment the study is focusing on granitic rocks), which may contribute to a better understanding of SEM phenomena, are already being undertaken.

Acknowledgements. The Portuguese team acknowledges the support of two Portuguese institutions: QREN support (Operational Program "Thematic Factors of Competitiveness"), co-funded by the European Regional Development Fund (ERDF), for the research program SIRAS, and the FCT (Science and Technology Foundation) for the grant SFRH/BPD/63880/2009 (HGS). Finally, we are grateful to the support from Samuel Bárias e Claúdia Serrano.

Edited by: K. Eftaxias

Reviewed by: C. Nomicos and another anonymous referee

\section{References}

Argus, D., Gordon, R., DeMets, C., and Stein, S.: Closure of the Africa-Eurasia-North America plate motion and tectonics of the Gloria fault, J. Geophys. Res. 94, 5585-5602, doi:10.1029/JB094iB05p05585, 1989.

Bezzeghoud M., Borges, J. F., Caldeira, B., Buforn, E., and Udías, A.: Seismic activity in the Azores Region in the context of the western part of the Eurasia-Nubia plate boundary, International Seminar on Seismic risk and rehabilitation on the 10th Anniversary of the July 91998 Azores Earthquake, Horta-Azores, 9-13 July, 27, 2008.

Bezzeghoud M., Borges, J. F., and Caldeira, B.: Fontes sísmicas ao longo da fronteira de placas tectónicas entre os Açores e a Argélia: um modelo sismotectónico, edited by: Dias, R., Araújo A., and Terrinha P., (Escolar Editora, Lisbon, Portugal), in press, 2010.

Biagi, P. F., Castellana, L., Maggipinto, T., and Ermini, A.: An overview on preseismic anomalies in LF radio signals revealed in Italy by wavelet analysis, Ann. Geophys., Ann. Geophys. 51(1), 237-246, 2008.

Biagi, P. F., Castellana, L., Maggipinto, T., Loiacono, D., Schiavulli, L., Ligonzo, T., Fiore, M., Suciu, E., and Ermini, A.: A pre seismic radio anomaly revealed in the area where the Abruzzo earthquake $(M=6.3)$ occurred on 6 April 2009, Nat. Hazards Earth Syst. Sci., 9, 1551-1556, doi:10.5194/nhess-91551-2009, 2009.

Bleier, T., Dunson, C., Maniscalco, M., Bryant, N., Bambery, R., and Freund, F.: Investigation of ULF magnetic pulsations, air conductivity changes, and infra red signatures associated with 
the 30 October Alum Rock M5.4 earthquake, Nat. Hazards Earth Syst. Sci., 9, 585-603, doi:10.5194/nhess-9-585-2009, 2009.

Borges, J., Fitas, A. J. S., Bezzeghoud, M., and Teves-Costa, P.: Seismotonics of Portugal and its adjacent Atlantic area, Tectonophysics 331(4), 373-387, doi:10.1016/S0040-1951(00)00291-2, 2001.

Borges J. F., Bezzeghoud, M., Buforn, E., Pro, C., and Fitas A.: The 1980, 1997 and 1998 Azores earthquakes and its seismotectonic implications, Tectonophysics, 435(1-4), 37-54, doi:10.1016/j.tecto.2007.01.008, 2007.

Borges, J. F., Caldeira, B., Bezzeghoud, M., and Buforn, E.: Seismicity and Seismotectonics of Azores: Geodynamic Implications, Ch. 6, 99-110, in A Book on the 1998 Azores earthquake 10 years after its occurrence, edited by: Oliveira C. S., Costa A., and Nunes, J. C., ISBN 978.989-20-1223-0, 741, 2008.

Buforn, E., Udías, A., and Colombás, M. A.: Seismicity, source mechanisms and seismotectonics of the AzoresGibraltar plate boundary, Tectonophysics, 152(1-2), 89-118, doi:10.1016/0040-1951(88)90031-5, 1988a.

Buforn, E., Udías, A. and Mézcua, J.: Seismicity and focal mechanisms in south Spain, Bull. Seism. Soc. Am. 78(6), 20082024, http://www.bssaonline.org/cgi/content/abstract/78/6/2008, 1988 b.

Buforn, E., Udías, A. and Madariaga, R.: Intermediate and deep earthquakes in Spain, Pageoph, 136(4), 375-393, doi:10.1007/BF00878576, 1991a.

Buforn, E., Udías, A., Mézcua, J. and Madariaga, R.: A deep earthquake under south Spain, 8 March 1990, Bull. Seism. Soc. Am., 81(4), 1403-1407, http://bssa.geoscienceworld.org/cgi/content/ citation/81/4/1403, 1991b.

Buforn E., Coca, P., Udías, A., and Lasa, C.: Source mechanism of intermediate and deep earthquakes in southern Spain, J. Seismol., 1(2), 113-130, doi:10.1023/A:1009754219459, 1997.

Buforn, E., Bezzeghoud, M., Udías, A., and Pro, C.: Seismic Sources on the Iberia-African Plate Boundary and their Tectonic Implications, Pure Appl. Geophys., 161(3), 623-646, doi:10.1007/s00024-003-2466-1, 2004.

Caldeira, B., Carrilho, F., Miranda, M., Bezzeghoud, M., Alves, P. M., Silveira, G., Villalonga, F., Pena, J. A., Matias, L., Borges, J. F., Vales, D., Corela, C., and Madureira, G.: Recent improvements in the Broadband seismic networks in Portugal, CSEM / EMSC Newsletter, 18-19, May 2007.

Chauhan, V., Singh, O. P., Kushwah, V., Singh, V., and Singh, B.: Ultra-low-frequency (ULF) and total electron content (TEC) anomalies observed at Agra and their association with regional earthquakes, J. Geodyn., 48(2), 68-74, doi:10.1016/j.jog.2009.06.002, 2009.

Gladychev, V., Baransky, L., Schekotov, A., Fedorov, E., Pokhotelov, O., Andreevsky, S., Rozhnoi, A., Khabazin, Y., Belyaev, G., Gorbatikov, A., Gordeev, E., Chebrov, V., Sinitsin, V., Lutikov, A., Yunga, S., Kosarev, G., Surkov, V., Molchanov, O., Hayakawa, M., Uyeda, S., Nagao, T., Hattori, K., and Noda, Y.: Study of electromagnetic emissions associated with seismic activity in Kamchatka region, Nat. Hazards Earth Syst. Sci., 1, 127-136, doi:10.5194/nhess-1-127-2001, 2001.

Grandin, R., Borges, J. F., Bezzeghoud, M., Caldeira, B., and Carrilho, F.: Simulations of strong ground motion in SW Iberia for the 1969 February $28\left(M_{S}=8.0\right)$ and the 1755 November $1(\mathrm{M}$ $\sim 8.5$ ) earthquakes - I. Velocity model, Geophys. J. Int., 171(3),
1144-1161, doi:10.1111/j.1365-246X.2007.03570.x, 2007a.

Grandin, R., Borges, J. F., Bezzeghoud, M., Caldeira, B., and Carrilho, F.: Simulations of strong ground motion in SW Iberia for the 1969 February $28\left(M_{S}=8.0\right)$ and the 1755 November $1(\mathrm{M} \sim 8.5)$ earthquakes - II. Strong ground motion simulations, Geophys. J. Int., 171(2), 807-822, doi: 10.1111/j.1365246X.2007.03571.x, 2007b.

Grimison, N. and Cheng, W.: The Azores-Gibraltar plate boundary: focal mechanisms, depths of earthquakes and their tectonic implications, J. Geophys. Res., 91(B2), 2029-2047, doi:10.1029/JB091iB02p02029, 1986.

Harrison, R. G., Aplin, K. L., and Rycroft, M. J.: Atmospheric electricity coupling between earthquake regions and the ionosphere, J. Atmos. Sol.-Terr. Phys., 72(5-6), 376-381, doi:10.1016/j.jastp.2009.12.004, 2010.

Hattori, K., Takahashi, I., Yoshino, C. C., Isezaki, N., Iwasaki, H., Harada, M., Kawabata, K., Kopytenko, E., Kopytenko, Y., Maltsev, P., Korepanov, V., Molchanov, O., Hayakawa, M., Noda, Y., Nagao, T., and Uyeda, S.: ULF geomagnetic field measurements in Japan and some recent results associated with Iwateken Nairiku Hokubu earthquake in 1998, Phys. Chem. Earth, 29(49), 481-494, doi:10.1016/j.pce.2003.09.019, 2004.

Hatzfeld, D.: Etude sismotectonique de la zone de collision IberoMaghrébine. Ph.D. Thesis, Grenoble (France), 281, 1978.

Munuera, J. M.: Datos básicos para un estudio de sismicidad en la región de la Península Ibérica, Mem. Inst. Geog. Cat., Madrid, 32, 93, 1963.

Nunes, J. C. and Ribeiro, E.: Caracterizaçao da sismicidade instrumental dos Açores no periodo 1950-1980, SISMICA, Encontro Nacional de Sismología e Enghenaria Sísmica, Açores, 2001.

Prattes, G., Schwingenschuh, K., Eichelberger, H. U., Magnes, W., Boudjada, M., Stachel, M., Vellante, M., Wesztergom, V., and Nenovski, P.: Multi-point ground-based ULF magnetic field observations in Europe during seismic active periods in 2004 and 2005, Nat. Hazards Earth Syst. Sci., 8, 501-507, doi:10.5194/nhess-8-501-2008, 2008.

Rocha, J. P., Bezzeghoud, M., Caldeira, B., Araújo, A., Borges, J. F., Vilallonga, F., and Dorbath, C.: Microseismicity in the neighbourhood of "Almodôvar fault", $6^{a}$ Assembleia Luso Espanhola de Geodesia e Geofísica, 2008 (in Portuguese).

Rozhnoi, A., Solovieva, M. S., Molchanov, O. A., and Hayakawa, M.: Middle latitude LF $(40 \mathrm{kHz})$ phase variations associated with earthquakes for quiet and disturbed geomagnetic conditions, Phys. Chem. Earth, 29(4-9), 589-598, doi:10.1016/j.pce.2003.08.061, 2004.

Searle, R.: Tectonic pattern of the Azores spreading centre and triple junction, Earth Plan. Sci. Lett., 51(2), 415-434, doi:10.1016/0012-821X(80)90221-6, 1980.

Seber, D., Barazangi, M., Ibenbrahim, A., and Demnati, A.: Geophysical evidence for lithospheric delamination beneath the Alboran Sea and Rif-Betic mountains, Nature, 379, 785-790, doi:10.1038/379785a0, 1996.

Serrano, I., Morales, J., Zhao, D., Torcal, F., and Vidal, F.: Pwave tomographic images in the Central Betics-Alboran Sea (south Spain) using local earthquakes: contribution for a continental collision, Geophys. Res. Lett., 25(21), 4031-4034, doi:10.1029/1998GL900021, 1998.

Silva, H. G., Bezzeghoud, M., Reis, A. H., Rosa, R. N., Tlemçani, M., Araújo, A. A., Caldeira, B., Borges, J. F., Serrano, C., and 
Biagi, P. F.: Atmospheric electrical field suppression in the time of the $M=4.1$ Sousel earthquake (Portugal), Nat. Hazards Earth Syst. Sci., in review, 2011.

Smirnov, S.: Association of the negative anomalies of the quasistatic electric field in atmosphere with Kamchatka seismicity, Nat. Hazards Earth Syst. Sci., 8, 745-749, doi:10.5194/nhess-8745-2008, 2008.

Telesca, L., Lapenna, V., Macchiato, M., and Hattori, K.: Investigating non-uniform scaling behavior in Ultra Low Frequency (ULF) earthquake-related geomagnetic signals, Earth Planet. Sci. Lett., 268(1-2), 219-224, doi:10.1016/j.epsl.2008.01.033, 2008.
Torné, M., Fernandez, M., Comas, M. C., and Soto, J. I.: Lithospheric structure beneath the Alboran basin: results from 3D gravity modeling and tectonic revelance, J. Geophys. Res. 105(B2), 3209-3228, doi:10.1029/1999JB900281, 2000.

Toutain, J. P. and Baubron, J. C.: Gas geochemistry and seismotectonics: a review, Tectonophysics, 304(1-2), 1-27, doi:10.1016/S0040-1951(98)00295-9, 1999.

Udías, A., López Arroyo, A. and Mézcua, J.: Seismotectonics of the Azores-Alboran region, Tectonophysics, 31(3-4), 259-289, doi:10.1016/0040-1951(76)90121-9, 1976. 